Scripta Neophilologica Posnaniensia. Tom XIII, strony: 203-210

Wydział Neofilologii, Uniwersytet im. Adama Mickiewicza w Poznaniu, 2013 DOI 10.7169/snp.2013.13.16

\title{
PRZESTRZEŃ \\ JAKO NOŚNIK TOŻSAMOŚCI NARODOWEJ W PIELGRZYMCE MOJÉJ DUSZY VÍCTORA BALAGUERA
}

\author{
BARBARA ŁUCZAK
}

Wiek XX jest dla twórczości literackiej uprawianej w języku katalońskim czasem rozkwitu. Twierdzenie to wydaje się zasadne, nawet jeśli weźmiemy pod uwagę, iż w latach dyktatury frankistowskiej w Hiszpanii (1939-1975) zwłaszcza najwcześniejszych - rozwój tej literatury został spowolniony, czy wręcz zahamowany. Nie należy jednak zapominać, iż podwaliny pod sukces odniesiony w XX stuleciu położono w wieku XIX, w okresie, który zbiegł się częściowo z epoką romantyzmu w literaturach europejskich i z niej czerpał inspiracje. W historii kultury katalońskiej nosi on nazwę „Renaixença” - odrodzenie. Za symboliczny początek Renaixençy zwykło się uznawać publikację utworu o znamiennym tytule „Ojczyzna (wiersz)” („La Pàtria [Trobes]”) Bonaventury Carlesa Aribau. Przeszedł on do historii jako „Oda do ojczyzny”. Jakkolwiek zabrzmieć to może dziwnie w tym kontekście, w rzeczywistości ma on charakter okolicznościowy - autor dedykuje go swojemu przełożonemu w dniu jego imie$\operatorname{nin}^{1}$. W tym dość krótkim utworze, który w roku 1833 został opublikowany w barcelońskim czasopiśmie El Vapor, pojawia się jednak temat tęsknoty za ojczyzną, pochwała rodzimego języka i odniesienia do krajobrazu Katalonii; elementy te wystarczyły, by poemat zyskał sławę manifestu patriotycznego. Renaixença oznacza bowiem dla Katalonii moment odrodzenia języka i literatury po przeszło dwóch wiekach utraty prestiżu na rzecz literatury hiszpańskiej i języka hiszpańskiego (czy kastylijskiego, jak często mówi się w Hiszpanii).

\footnotetext{
${ }^{1}$ Przełożony zwał się Gaspar de Remisa, a zatem prezent otrzymał w święto Trzech Króli, w roku 1833.
} 
Nie jest to zresztą ruch na Półwyspie Iberyjskim odosobniony - równolegle do katalońskiego odrodzenia rozwija się odrodzenie galisyjskie, Rexurdimento, choć nie ma aż tak wielkiej siły, gdyż o mocy Renaixençy przesądza pozycja katalońskiej, przede wszystkim barcelońskiej burżuazji, wzrastającej w bogactwo i wpływy. Mówi się również o odrodzeniu baskijskim, choć ten proces jest bardziej rozciągnięty w czasie i nawet jeśli wyrasta $\mathrm{z}$ ruchu romantycznego, odznacza się odmienną dynamiką ${ }^{2}$.

Chcąc doprowadzić do odrodzenia rodzimej literatury, katalońska Renaixença wypracowuje repertuar symboli i odniesień kulturowych, na których oprzeć chce tradycję patriotyczną, umacniając tym samym tożsamość narodową. Przybliżę niektóre jego elementy, odwołując się do wiersza Víctora Balaguera (1824-1901), „Lo romiatge de l'ànima”. Utwór ten wydany został w roku 1891 w dwujęzycznej edycji łączącej kataloński oryginał z przekładem na hiszpański pióra samego autora. Wersja hiszpańskojęzyczna była kilkakrotnie poprawiana i ponownie prezentowana iberyjskiemu czytelnikowi. W roku 1898 wiersz został przetłumaczony na język polski przez Reginę Szymońską. Przekład, zatytułowany „Pielgrzymka mojéj duszy”, ukazał się w warszawskim czasopiśmie Ateneum (Balaguer, 1898).

Autor wiersza, Víctor Balaguer, jest jedną z najważniejszych postaci XIX-wiecznego odrodzenia katalońskiego. Pisał o nim już Edward Porębowicz ${ }^{3}$ w studium zatytułowanym Ruch literacki południowo-zachodniej Europy. Składa się na nie cykl artykułów opublikowanych w latach 1888-1889 w Przeglądzie Polskim - jeden z nich poświęcony został właśnie literaturze katalońskiej ${ }^{4}$. O pracy tej warto pamiętać, gdyż w historii polskiej katalonistyki ma charakter pionierski, nawet jeśli we wcześniejszym piśmiennictwie, przede wszystkim w Wielkiej Encyklopedyi Powszechnej Ilustrowanej, pojawiały się informacje dotyczące Katalonii, jej literatury i kultury ${ }^{5}$. Stosunek Porębowicza do twórczo-

\footnotetext{
${ }^{2}$ Tematyka XIX-wiecznego odrodzenia galisyjskiego była omawiana w polskim piśmiennictwie literaturoznawczym. Odsyłam do artykułów przedstawionych w Studiach iberystycznych (2003) oraz w Loba, Łuczak i Gregori (2012). W tym ostatnim tomie, w suplemencie dołączonym do artykułu Piotra Sawickiego (2012: 42-44), odnajdujemy hasło słownikowe poświęcone literaturze baskijskiej, zawierające również informacje dotyczące odrodzenia baskijskiego.

${ }^{3}$ Jeszcze wcześniej, w roku 1883, autor „Kroniki” Biblioteki Warszawskiej odnotowywał przyjęcie Víctora Balaguera do Królewskiej Akademii Hiszpańskiej i streszczał najważniejsze tezy jego pierwszej mowy akademickiej, a w roku 1891, w V tomie Wielkiej Encyklopedyi Powszechnej Ilustrowanej ukazał się obszerny biogram pisarza.

${ }^{4}$ Równolegle ukazało się wydanie książkowe. Pracę Porębowicza cytuję za przedrukiem z roku 1951, noszącym tytuł „Po obu stronach Pirenejów”, a ujętym w Studiach literackich (Porębowicz, 1951).

${ }^{5} \mathrm{O}$ najwcześniejszej recepcji kultury i literatury katalońskiej pisali w języku polskim: Sawicka (2007), Sawicki (2007), Łuczak (2007b) i in.
} 
ści i postaci Víctora Balaguera jest ambiwalentny. Zrazu pisze on, iż w dziele katalońskiego poety ,[p]o raz pierwszy w odrodzonej literaturze ozwał się znaczący wyraz Wolność; odtąd Balaguer służy jej pieśnią i czynem” (1951: 173). Zaraz jednak pozwala sobie na serię ironicznych uwag, stwierdzając, iż Katalończyk udał się na wygnanie „w wieńcu niby cierniowym, lecz podbitym watą; rok 1867 spędził mile u Prowansalczyków”, a „,[n]astępnego roku wrócił z 'wygnania"” i stał się czynnym uczestnikiem życia politycznego (1951: 176). ,[T]en patriota-fanatyk 'zoportunizował się' i jest dziś [...] oczywiście - ministrem”, podsumowuje Porębowicz (1951: 173). Wydaje się, iż polski krytyk, choć ceni twórczość Balaguera, nie może mu wybaczyć odstąpienia od wyraziście formułowanych patriotycznych postulatów ${ }^{6}$. Opinie Porębowicza wyraźnie wpisują się w dynamikę napięć między Katalonią a Kastylią, między Barceloną a Madrytem, które znaczą ideologiczny dyskurs Renaixençy (zob. również Łuczak, 2007b: 111).

Już sam tytuł poematu Balaguera - „Pielgrzymka mojéj duszy” - sugeruje, iż element przestrzenny pełni istotną funkcję $\mathrm{w}$ procesie kreowania znaczeń w tekście. Zasadniczą osią konstrukcyjną utworu jest właśnie wędrówka owej tytułowej duszy, o której polski przekład, w partii otwierającej wiersz, mówi, iż „powstaje” w podmiocie lirycznym, by odwiedzić miejsca, w których razem z nim śpiewała na cześć „wiary, ojczyzny i miłości”. Wprowadzony motyw wędrówki pozwala Balaguerowi zaprezentować całą serię miejsc symbolicznych, o szczególnym znaczeniu dla katalońskiej tożsamości narodowej. Już w tej wstępnej deklaracji odnajdujemy element przywodzący na myśl proces odrodzenia języka katalońskiego. „Wiara, ojczyzna, miłość” to nawiązanie do formuły „Patria, Fides, Amor” będącej hasłem tzw. gier kwiatowych (kat. „Jocs Florals”), czyli konkursu poetyckiego, który nawiązywał, zarówno ideą, jak i nazwą, do średniowiecznego współzawodnictwa poetów (pierwsze gry kwiatowe odbyły się w Tuluzie, w roku 1323) ${ }^{7}$. Przywrócenie tego zwyczaju i zorganizowanie pierwszego konkursu Jocs Florals w Barcelonie w 1859 roku było istotnym wydarzeniem w historii Renaixençy i w dziejach XIX-wiecznej literatury katalońskiej. Przeprowadzanie tego typu turniejów unaoczniało tradycję, do jakiej Renaixença chciała nawiązać, a było to dziedzictwo średniowiecznej Katalonii. Postrzegano ją jako przestrzeń symboliczną - językową i kulturową - nieroz-

\footnotetext{
${ }^{6} \mathrm{Z}$ większą sympatią odnosi się do innego przedstawiciela Renaixençy katalońskiej, Francesca Pelagi Briza, o którym pisze: „dziś złamany cierpieniem nerwowym, nie pracuje już wiele i stoi wobec nowych kierunków cokolwiek na boku; rad jednak, gdy go odwiedzisz, melodię znad Wisły ci zagra i tomiki Mickiewicza, Malczewskiego w przekładzie ukaże" (Porębowicz, 1951: 177).

${ }^{7}$ Termin ,jocs florals” na język polski tłumaczony był również jako „igrzyska kwiatowe”, „zabawy kwiatowe” czy ,święto kwiatów”.
} 
łącznie związaną z Prowansją, z językiem prowansalskim i z kulturą prowansalską $^{8}$. Nie trzeba też dodawać, iż zauważalny w tej tradycji ruch odśrodkowy, owo swoiste „wychylanie się" za Pireneje miało wymiar ideologiczny. Podkreślanie powinowactwa $\mathrm{z}$ krainami zapirenejskimi sugerowało bowiem równoczesny brak silnych związków historycznych z Madrytem.

W początkowej partii wiersza podmiot przywołuje zatem chwilę, w której dusza, powstawszy w nim, uleciała ,nad wybrzeżem suburskiém”. W wersji hiszpańskiej z roku 1897, będącej prawdopodobną podstawą polskiego przekładu, czytamy w przypisie ${ }^{9}$, iż przymiotnik ,suburense” odnosi się do starożytnej Subur (,la antigua Subur”; Balaguer, 1897: 61), którą poeta utożsamia z miejscowością Sitges znajdującą się nieopodal Vilanova i la Geltrú, gdzie dusza rozpoczyna swą wędrówkę. Wydaje się, iż podane przez Balaguera wyjaśnienie wpisuje się w ogólniejszą strategię zastosowaną w utworze. Pielgrzymka duszy rozpoczyna się „tu i teraz”: gdy „wybiła północ”, „[dusza] wzbiła się w przestworza, pozostawiając w białym i czerwonym domku samotnego, bom został bez niéj" (Balaguer, 1898: 201), czytamy w poemacie, a kolejny przypis wyjaśnia, iż autor mówi o znajdującym się w miejscowości Vilanova domu, w którym powstał utwór. Zaraz jednak perspektywa czasoprzestrzenna ulega poszerzeniu. Motyw podróży pozwala włączyć w nią nowe obszary, a nawiązania do dziejów minionych rozciągają ją w czasie. Tym samym „tu i teraz” podmiotu zagnieżdżają się w przestrzeni i dziejach Katalonii, o których mówi wiersz, stając się ich integralną częścią. Tuż potem pojawia się inne odniesienie do topografii okolic Sitges - królujące nad wybrzeżem szczyty masywu Garraf, które są znakiem rozpoznawczym tamtego regionu. $\mathrm{Z}$ okolic najbliższych podmiotowi dusza przenosi się ku „pięknej równinie, zroszonej przez szumiący Lobregat” (sic) (Balaguer, 1898: 202). Obraz ten bez wątpienia ma charakter emblematyczny i wyraźnie idylliczny. Stąd blisko już do Barcelony, która opisana jest jako „szlachetne miasto o hrabiowskim dyademie”, a formuła ta nawiązuje wyraźnie do świetności średniowiecznej Katalonii i jej stolicy.

Przemierzając miejsca ważne dla tożsamości narodowej, dusza poety odwiedza również klasztor Montserrat, którego symboliczne i religijne znaczenie opisywał w swym studium jeszcze Porębowicz, porównując go do częstochowskiej Jasnej Góry: „Montserrat z posągiem Matki Boskiej to nasza Jasna góra, dla Katalończyka święty chram narodowego ołtarza" (1951: 173). Pozwala to poecie wywiązać się z kolejnego zadania wynikającego z przywołanego na początku

\footnotetext{
${ }^{8} \mathrm{Z}$ terminologicznego punktu widzenia właściwsze byłoby zapewne zastosowanie terminów ,język oksytański” i „Oksytania” na oznaczenie terenu, na którym język ten jest używany, gdyż prowansalski jest dialektem oksytańskiego. Jednak termin ,prowansalski” przyjął się w polskiej tradycji romanistycznej i dlatego się nim posługuję.

${ }^{9}$ Szymońska przytacza zasadniczą część tego przypisu w swoim przekładzie.
} 
hasła „Patria, Fides, Amor”, gdyż w miejscu tym dusza śpiewa hymn ku czci Dziewicy Maryi (wcześniej, „unosząc się nad Barceloną [...], zaintonowała psalm miłości" [Balaguer, 1898: 202]). Tuż potem przenosi się w Pireneje, gdzie bierze udział w zgromadzeniu umarłych - obrońców ojczyzny. Tu z kolei wsłuchuje się w pieśń ostatniego trubadura, który wyśpiewuje swój ostatni, jak pisze Szymońska, „sirventesio”. Powtórzenie przymiotnika „ostatni” nie jest, rzecz jasna, przypadkowe, w tym wierszu mówiącym o czasach, które przeminęły.

Przekładając poemat $\mathrm{z}$ języka hiszpańskiego, polska tłumaczka używa terminu „sirventesio” (hiszp. serventesio), na oznaczenie sirventès, jednego z najważniejszych gatunków poezji prowansalskiej. W polskiej terminologii funkcjonuje też termin ,sirwent”, którym będę się posługiwać (zob. np. Kostkiewiczowa, 1976). Już samo odwołanie do tego gatunku jest znaczące. Sirwent bowiem, jak czytamy w Doctrina de compondre dictatz, XIII-wiecznym prowansalskim traktacie poetyckim, ,winien mieć za przedmiot czyny wojenne [...] lub też jakieś świeżej daty wydarzenie, o którym jest w świecie mowa" (Łukasik, 2006: 705). Jedną z kategorii tego gatunku jest sirwent polityczny, który przyjmował często formę pamfletu bądź manifestu. Formę sirwentu wykorzystywali na przykład autorzy pieśni krzyżowych ${ }^{10}$.

$\mathrm{W}$ poemacie Balaguera sirwent (który w oryginale katalońskim jest zgodnie z tradycją utworem wierszowanym, choć na hiszpański i polski przełożony został prozą) opowiada o wyprawie Szymona de Montfort przeciw albigensom i o końcu niepodległej Prowansji, którego najazd ten stał się przyczyną. Głos liryczny zwraca się tutaj do Pirenejów i to one są odbiorcą ostatniej pieśni trubadura i najważniejszym jej bohaterem. To Pireneje widziały najazd „niecnego Monforta” (sic) z ,piorunem zamiast szabli” (Balaguer, 1898: 206) i śmierć obrońców Prowansji; to o granie Pirenejów odbił się krzyk bólu, rozpaczy i śmierci. Ten głos zresztą, mówi poeta, wciąż powraca, wzywając do działania, zwłaszcza że cienie przodków gromadzące się w ruinach zamku hrabiego de Foix są, zgodnie z polskim przekładem, wciąż „nieuspokojone” (Balaguer, 1898: 205); kataloński oryginał i hiszpański przekład mówią w tym miejscu o cieniach „niepomszczonych” (1897: 42 i 78), podkreślając jeszcze mocniej aktualność minionych zdarzeń i konieczność działania w czasie teraźniejszym (zob. również Łuczak, 2007a: 272). W wierszu Balaguera Pireneje przedstawione są zatem jako świadek, który swą obecnością wzywa do czynu. Podmiot liryczny zwraca się też do nich słowami: „Wy, które nie mogąc pomieścić się w jednym, należycie do dwóch krajów; łącząc je i dzieląc zarazem" (Balaguer, 1898: 207). Pireneje oddzielają Katalonię od Prowansji, ale i scalają, będąc wewnętrzną granicą między częściami większego organizmu. Nie negując zatem odrębności obu tych

\footnotetext{
${ }^{10} \mathrm{~W}$ Łuczak (2007a) analizowałam przekład wiersza Balaguera na język hiszpański i polski. Teraz, z innej perspektywy, wracam do niektórych omówionych tam treści.
} 
krain, Balaguer podkreśla zarazem, iż tworzą wspólnotę. Więzy te ulegną rozpadowi właśnie wskutek wyprawy Szymona de Montfort, o której traktuje sirwent. W 1271 roku Tuluza zostanie włączona do Korony Francuskiej i w ten sposób skończy się pewna epoka w historii Katalonii i Prowansji, przeciwstawionych "Północy”. Wiersz nie pozostawia wątpliwości, iż rozpad ich jedności był w istocie rozdarciem, dokonanym przemocą i znaczonym śmiercią: ,gdy zgłodniali mieszkańcy północy przybyli do téj ziemi, jak gromada wilków, a ciała ludzkie służyły za drwa do podsycania ognia i gdy okrzyk śmierci zabrzmiał na zamku o trzech czerwonych wieżycach" (Balaguer, 1898: 206) ${ }^{11}$.

W sirwencie pojawia się też temat wspólnoty języka, gdyż podmiot zwraca się do ziem limuzyńskich, które „po limuzyńsku czują i po limuzyńsku mówią” (w katalońskim oryginale i w hiszpańskojęzycznej wersji ${ }^{12}$ ). Owa mowa limuzyńska czy - szerzej - cała grupa znaczeń powiązana z przymiotnikiem „limuzyński” jest kolejnym ważnym elementem obrazowości patriotycznej. Użycie terminu „limuzyński” w piśmiennictwie Renaixençy było nie do końca konsekwentne, a granice jego pola semantycznego - nieostre. W ścisłym znaczeniu przymiotnik ten, podobnie jak przymiotnik ,prowansalski”, powinien być stosowany na określenie jednego z dialektów języka oksytańskiego, ale oznaczano nim cały język oksytański, kataloński, który w pewnym okresie uległ wpływom oksytańskiego, a czasem stosowano jako synonim „katalońskiego” (Badia i Margarit, 1984: 4). Właśnie w tym znaczeniu używa go Aribau we wspomnianej wcześniej „Odzie do ojczyzny”. Stosując ten termin, Balaguer, osadza swój utwór, zgodnie z duchem Renaixençy, we wspólnej tradycji związków z Prowansją. To pozwala mu zamknąć wiersz „Pieśnią o ziemi limuzyńskiej”, w której woła: „Ziemio limuzyńska! Ziemio mojego serca! Kraju miłości” [...] (Balaguer, 1898: 209). I zwróćmy uwagę, że ów „kraj” z przekładu Szymońskiej to w katalońskim oryginale i w hiszpańskiej wersji „Marca”, czyli Marchia - Marchia Hiszpańska. Autor poematu wyjaśnia w przypisie, a za nim czyni to również polska thumaczka, iż „[j]est tu mowa o ziemiach: Rousillonie (sic), Katalonii i Walencyi" (Balaguer, 1898: 209), a zatem o terenach położonych po obu stronach Pirenejów. W ten sposób raz jeszcze podkreśla formułę tożsamości wykraczającą poza obszar Półwyspu Iberyjskiego, którego centrum wyznacza Madryt.

Odnosząc się do ostatniej części poematu Balaguera, nie sposób pominąc roli, jaką w przekazywaniu tradycji narodowej i patriotycznej odgrywa poeta, bard.

\footnotetext{
${ }^{11}$ Zarówno w katalońskim oryginale, jak i w hiszpańskiej wersji słowo ,północ” pisane jest z wielkiej litery (kat. Nort, hiszp. Norte), co wyraźniej niż w polskim przekładzie uwypukla polityczne (a nie jedynie geograficzne) znaczenie terminu.

${ }^{12}$ Polski przekład nie jest im wierny, gdyż frazę „Sława i pokój wam, o ziemie limuzyńskie, które po limuzyńsku czujecie i po limuzyńsku mówicie” (przeł. BŁ) zastępuje formułą: „Sława i pokój wam, ziemie limuzyńskie i tym, co mówią i czują po limuzyńsku" (Balaguer, 1898: 208).
} 
Jeśli bowiem ostatni trubadur wyśpiewał po klęsce albigensów swój ostatni sirwent, zamykając okres dziejów Katalonii zwróconej ku Prowansji, podmiot wiersza Balaguera ponownie go otwiera, śpiewając na cześć ziem limuzyńskich położonych po obu stronach Pirenejów. Bez wątpienia w poemacie Balaguera odnajdujemy wiele elementów, które pozwalają wpisać go w krąg tradycji romantycznej. Z ogólnoeuropejskiego romantycznego ferworu Balaguer i katalońska Renaixença przejęły fascynację średniowieczem. W tym przypadku jednak fascynacja ta nie stanowiła jedynie fantazyjnej próby powrotu do wyimaginowanych ideałów, lecz posiadała konkretny wymiar tożsamościowy i kulturowy. Nawet jeśli projekt ten nie miał nigdy urzeczywistnić się w realnej przestrzeni politycznej, stawał się wyznacznikiem dążeń i zbiorowych pragnień.

\section{Bibliografia}

Badia i Margarit, A.M. 1984. Gramàtica històrica catalana. València: Edicions 3 i 4.

Balaguer, V. 1897. Lo romiatge de l'ànima. La romería del alma. Poema original catalán y versión castellana. Barcelona: Tipografia de Lluis Tasso.

Balaguer, V. 1898. „Pielgrzymka mojéj duszy”. Przeł. Regina Szymońska. Ateneum. Pismo naukowe i literackie 2. 201-208.

Kostkiewiczowa, T. 1976. „Sirwent”. W zbiorze: Sławiński, J. (red.). Słownik terminów literackich. Wrocław: Zakład Narodowy im. Ossolińskich. 405.

„Kronika”. 1883. Biblioteka Warszawska. Tom 2. 284-286.

Loba, M., Łuczak, B. i A. Gregori. (red.). 2012. „Literatury mniejsze” Europy romańskiej. Poznań: Wydawnictwo Naukowe UAM.

Łuczak, B. 2007a. „«Albowiem nie mają tej samej mocy słowa czytane w języku hebrajskim, co przełożone na inną mowę». O polskim i hiszpańskim przekładzie pewnego katalońskiego poematu". W zbiorze: Szczęsny, A. i K. Hejwowski. (red.). Językowy obraz świata w oryginale $i$ przekładzie. Siedlce: Instytut Lingwistyki Stosowanej Uniwersytetu Warszawskiego. 265-276.

Łuczak, B. 2007b. „Allò que els meus besavis podien saber...: recepció de la literatura catalana a Polònia a cavall dels segles XIX i XX”. W zbiorze: Jornades de catalanística a Praga. Andorra la Vella: Ministeri del Portaveu, Cultura i Ensenyament Superior del Govern d'Andorra. $108-117$.

Łukasik, S. 2006. „Sirventès”. W zbiorze: Gazda, G. i S. Tynecka-Makowska. (red.). Słownik rodzajów i gatunków literackich. Kraków: Universitas. 705-708.

Porębowicz, E. 1951. „Literatura katalońska”. W zbiorze: Porębowicz, E. Studia literackie. Kraków: Wydawnictwo M. Kot. 168-187.

Sawicka, A. 2007. „Listy z Polski w korespondencji JacintaVerdaguera. Kataloński epizod naukowych peregrynacji Edwarda Porębowicza”. Prace Komisji Filologicznej (Polska Akademia Umiejętności). Tom VI. 141- 160.

Sawicki, P. 2007. „Literatura katalońska w polskich encyklopediach powszechnych i podręcznikach literatury". Studia iberystyczne 6. (Almanach Kataloński. Katalonia-Walencja-BalearyAndorra). 141-170. 
Sawicki, P. 2012. „«Literatury mniejsze» Hiszpanii w podręcznikach i encyklopediach PWN-owskich”. W zbiorze: Loba, M., Łuczak, B. i A. Gregori. (red.). „Literatury mniejsze” Europy romańskiej. Poznań: Wydawnictwo Naukowe UAM. 35-46.

Studia iberystyczne. 2003. Álvarez Lugrís, A., Eminowicz-Jaśkowska, T. i M. Filipowicz-Rudek. (red.). Nr 2. (Almanach Galicyjski). Kraków: Księgarnia Akademicka. 